John M. Murkin MD FRCPC

\title{
Neuroprotection, anaesthesia, and the brain
}

In clinical practice, the occurrence of both focal and global cerebral ischaemia can be observed during various situations including during cardiac surgery and circulatory arrest. Mechanisms of injury including cerebral emboli and global ischaemia, and the role of excitotoxicity and potential pharmacological interventions, will be reviewed.

\section{Focal ischaemia}

There is both indirect and direct evidence that focal ischaemic insult occurs during cardiopulmonary bypass (CPB) as a result of microgaseous and particulate emboli. The risk of embolization is influenced by several factors including type of CPB equipment employed, e.g., usage of arterial line filtration, bubble vs membrane oxygenators. $^{1-4}$ In addition, transcranial Doppler (TCD) studies have detected emboli occurring during both aortic cannulation and clamping, as well as during stable CPB. ${ }^{5}$ Retinal imaging has demonstrated perfusion defects indicative of embolization, that are decreased by use of a membrane oxygenator. ${ }^{6}$ Histological studies in both experimental animals and patients exposed to $\mathrm{CPB}$, as well as in patients undergoing proximal aortography only, have demonstrated brain microvascular lesions consistent with cerebral emboli. ${ }^{7}$

Distinct from microemboli, the extent of aortic atherosclerosis is likely and an independent risk for overt neurological damage and cerebrovascular accident. This is both a result of fracturing and fragmentation that can occur with aortic instrumentation, as well as "shearing" of plaque as a consequence of the hydrodynamic changes from perfusion through the aortic cannula. The risk of overt neurological dysfunction associated with coronary artery bypass (CAB) surgery is generally reported to be $<2 \%{ }^{8,9}$ There is a high incidence of subtle postoperative neuropsychological dysfunction, variously reported to occur in between $48 \%$ to $79 \%$ of patients undergoing $\mathrm{CAB}$ surgery. ${ }^{8,10-12}$ The aetiology and importance of this cognitive dysfunction is unclear, but it is felt to reflect cerebral ischaemia occurring as a result of episodes of hypoperfusion ${ }^{13}$ and/or gaseous and particulate microemboli during cardiopulmonary bypass (CPB). ${ }^{7,8} \mathrm{In}$ addition, such cognitive dysfunction may also be partly attributable to nonspecific stress associated with under- going major surgery, and is at least partly independent of exposure to CPB., 10

\section{Global ischaemia}

In clinical practice, episodes of controlled global ischaemia are associated with procedures for implantable cardiovertor-defibrillator (ICD) insertion, and those employing deep hypothermic circulatory arrest (DHCA), e.g., aortic arch reconstruction and repair of congenital heart lesions. Since ICD procedures involve multiple episodes of cardiac arrest, such procedures, particularly when superimposed upon incipient or overt cerebrovascular disease (estimated as an associated phenomenon in over $60 \%$ of patients with atherosclerotic heart disease), represent multiple episodes of complete global cerebral ischaemia. While the episodes of ventricular tachycardia or fibrillation (VT or VF) are limited to durations of $60 \mathrm{sec}$ or less, this is sufficient to induce loss of consciousness, cause cessation of cerebral blood flow (CBF), and temporarily disrupt cerebral metabolic processes.

In one of the few available clinical studies of cerebral physiology in ICD patients, ${ }^{14}$ a reperfusion hyperoxic response was noted to occur after episodes of circulatory arrest of greater than $37 \mathrm{sec}$. The magnitude of the reperfusion response corresponded approximately to the duration of circulatory arrest. This cerebral hyperoxic reperfusion response likely represents transient postischaemic cerebral vasodilatation as observed with TCD during ICD procedures. ${ }^{15}$ This indicates a requirement for cerebral reperfusion, the duration of which has not been well quantitated. There are a few studies available examining the recovery rates of cerebral metabolic function an hour or more after brief episodes of global cerebral ischaemia, although currently there are no studies examining recovery rates of cerebral metabolism within a few minutes of a brief ischaemic event. Of those that are available, after $60 \mathrm{sec}$ ischaemia followed by $90 \mathrm{~min}$ reperfusion, although lactate, adenylate energy charge, and lactate/pyruvate ratio had returned to control, phosphocreatinine (PCr) and adenosine triphosphate (ATP) levels were still below control values. ${ }^{16,17}$ The evidence of post-

From the Department of Anaesthesia, University Hospital, University of Western Ontario, London, Ontario. 
operative cognitive dysfunction in patients after ICD procedures is variable, ${ }^{18}$ but recently it has been reported that the reperfusion interval between successive periods of VF-induced ischaemia is critical, neuropsychological dysfunction being observed with reperfusion intervals of three minutes or less but not with those exceeding four minutes. ${ }^{19}$ This indicates that current clinical practice, which varies by centre and by operator, should allow a minimum five-minute reperfusion interval for cerebral recovery between successive arrhythmia induction.

\section{Deep hypothermic circulatory arrest}

Hypothermia is the primary component of brain protection during DHCA. Over a range of $20^{\circ} \mathrm{C}\left(37^{\circ}\right.$ to $17^{\circ} \mathrm{C}$ ), the temperature coefficient (Q10) of the brain averages $3.65,{ }^{20}$ thus cerebral tolerance for ischaemia is greatly increased. Decreasing rewarming of the brain is essential, thus external heat sources, e.g., overhead lights, ambient room temperature, should be minimized. Application of external ice packs to the head has been shown experimentally to delay brain rewarming and increase ischaemic tolerance. Because of cerebral autoregulation with preferential shunting of blood to the brain, even low perfusion rates (e.g., $10-25 \mathrm{ml} \cdot \mathrm{kg}^{-1} \cdot \mathrm{min}^{-1}$ ) during deep hypothermia have been shown to improve cerebral ischaemic tolerance considerably in comparison with total circulatory arrest. A recent prospective randomized clinical trial has demonstrated a lower incidence of postoperative seizures in infants undergoing cardiac surgery using low flow $\left(0.7 \mathrm{~L} \cdot \mathrm{m}^{-2} \cdot \mathrm{min}^{-1}\right) \mathrm{CPB}$ in comparison with DHCA. ${ }^{21}$ Experimental studies during DHCA have demonstrated more homogeneous brain cooling using $\mathrm{pH}$ stat, but alpha-stat has been shown to be associated with lesser intracellular acidosis than $\mathrm{pH}$-stat during rewarming. ${ }^{22}$ However, in a retrospective study of the influence of $\mathrm{pH}$ management on developmental outcome after DHCA, it was concluded that alpha-stat may be associated with less effective cerebral protection. ${ }^{23}$

For aortic arch procedures where arterial inflow is restricted, selective cerebral perfusion via brachiocephalic or carotid cannulation has been utilized successfully. ${ }^{24}$ Increasing interest is developing in retrograde cerebral perfusion through SVC cannula, though prospective clinical outcome studies are not yet available. It appears that, independent of the substrate composition of cerebroplegic solutions, the washout of toxic metabolites, and prevention early rewarming of the brain, are the factors of paramount importance in the provision of cerebroprotective measures during DHCA.

Functional and biochemical changes in ischaemia Slowing of EEG with increases in low frequency power (delta band) are indicative of cerebral ischaemia. ${ }^{25}$ During anaesthesia the delay from onset of circulatory arrest to EEG changes of ischaemia is $20 \mathrm{sec}^{26,27}$ In animals the EEG disappears after 15-25 sec, corneal reflex in 10-90 $\mathrm{sec}$, and spontaneous respiration in $30-120 \mathrm{sec}$ after circulatory arrest. ${ }^{28}$ Studies of complete global ischaemia using neck tourniquets in normal and schizophrenic subjects demonstrated loss of consciousness in six to seven seconds with concomitant slowing of the EEG, followed by isoelectric EEG after $20-40 \mathrm{sec}^{25}$ Tonic clonic seizures and periods of transient postischaemic confusion followed ischaemic periods sustained for up to $100 \mathrm{sec}^{25}$ In monkeys, global cerebral ischaemia of three minutes or longer resulted in slowly resolving, or nonresolving, gross functional neurological deficits. ${ }^{29}$

Cerebral oxygen levels are depleted within a very few seconds of the onset of ischaemia. Biochemical changes, including a 50\% reduction in ATP and $85 \%$ decrease in $\mathrm{PCr}$, occur after $30 \mathrm{sec}$ global ischaemia in mice, ${ }^{30}$ with similar changes observed in human cerebral cortex. ${ }^{31}$ In mouse brain at $60 \mathrm{sec}$ following decapitation, $\mathrm{PCr}$, glucose, and glycogen stores were less than $10 \%$, ATP was less than $25 \%$ of control, and lactate had increased to $75 \%$ of its maximal value. ${ }^{32}$ In rats $60 \mathrm{sec}$ ischaemia induced $250 \%$ increases in adenosine and lactate, and measurable decreases in $\mathrm{PCr}$ were seen after the first five seconds of ischaemia. ${ }^{33}$ Even brief periods of cerebral ischaemia can thus be seen to induce profound functional and metabolic changes in animals as well as in humans.

Some of the earliest cell membrane changes with ischaemia involve production of free fatty acids (FFA) from membrane phospholipids. With ischaemia, ATP depletion causes loss of ionic gradients resulting in cell membrane depolarization and influx of calcium ion $\left(\mathrm{Ca}^{++}\right)$ through voltage-sensitive channels. Intracellular accumulation of excess $\mathrm{Ca}^{++}$leads to neuronal death via enhanced protein and lipid catabolism. Intracellular $\mathrm{Ca}^{++}$ activates calcium dependent phospholipases $\mathrm{C}$ and $\mathrm{A} 2$, transforming membrane phospholipids into FFA, which are in themselves neurotoxic. The FFAs are powerful uncouplers of oxidative phosphorylation and can undergo further oxidation from arachidonic acid, with resultant free radical formation. With reperfusion, mitochondrial cyclooxygenase and lipooxygenase pathways, in conjunction with oxidation of FFAs, are primarily responsible for heightened free radical (e.g., superoxide anion) formation, to produce oxidative cellular destruction.

\section{Excitotoxicity}

Neurotransmitter-induced excitotoxicity may be the final common pathway producing ischaemic cerebral injury. ${ }^{34}$ Glutamate and aspartate are excitatory amino acid (EAA) neurotransmitters, with three distinct postsynaptic 
receptor subtypes, N-methyl-D-aspartate (NMDA), kainate (KA) and quisqualate/alpha-methyl propionic acid (AMPA), responsible for mediating $\mathrm{Ca}^{++}$and $\mathrm{Na}^{+} / \mathrm{K}^{+}$passage. Ischaemia produces massive presynaptic EAA release and decreased reuptake, causing activation of postsynaptic NMDA and AMPA receptors, producing massive efflux of $\mathrm{K}^{+}$and influx of $\mathrm{Na}^{+} \mathrm{Ca}^{++}$ and resultant osmolysis and calcium-related damage. The EAAs are also implicated in free radical formation.

Mild hypothermia $\left(<35^{\circ} \mathrm{C}\right)$ substantially inhibits ischaemia-induced EAA release. In animals the tolerance for cerebral ischaemia has been shown to be prolonged disproportionately during mild hypothermia at $34^{\circ} \mathrm{C} .35$ In rats subjected to four-vessel occlusion of the cerebral circulation, despite severe depletion of brain energy metabolites during ischaemia at all temperatures, small increments of intraischaemic brain temperature markedly accentuated histopathological changes following three days survival, such that ischaemic neurones within the central zone of striatum were not observed in any rats treated at $34^{\circ} \mathrm{C}$, but were present in all rats maintained at $36^{\circ} \mathrm{C}^{36}$ In contradistinction to the salutary effect of mild hypothermia, normothermia or hyperthermia to $40.6^{\circ} \mathrm{C}$ has been demonstrated to markedly decrease the tolerance to ischaemia and impairs metabolic recovery after transient global cerebral ischaemia. ${ }^{36,37}$ Unrecognized hyperthermia may often attend hypothermic CPB. In clinical practice, this can be observed during the rewarming phase from hypothermia when nasopharyngeal temperature often exceeds $38^{\circ} \mathrm{C}$ and may reach $39^{\circ} \mathrm{C}$, depending upon the temperature of the arterial blood during rewarming, and the expediency with which rewarming is accomplished.

\section{Glucose/lactic acidosis}

Glucose is essentially the sole substrate for energy production by the brain, being metabolized to produce 36 to 38 moles ATP per mole glucose. Oxygen is essential for oxidative phosphorylation and in the presence of ischaemia, anaerobic glucose metabolism yields only two moles ATP and results in lactate production with accumulation of hydrogen ion $\left(\mathrm{H}^{+}\right)$. Anaerobic glycolysis is the primary cause of acidosis during ischaemia, and the severity of lactic acidosis is directly related to pre-ischaemia glucose concentrations. ${ }^{38}$ This reflects anaerobic conversion of glucose to lactate, resulting in a decrease in intracellular $\mathrm{pH}$ and impairment of cellular metabolism, primarily through inhibition of mitochondrial function during ischaemia and reperfusion. With incomplete ischaemia, "trickle flow" of glucose to the brain during ischaemia results in ongoing lactate metabolism and worsening of acidosis. ${ }^{39}$ In clinical studies glucose values above $150 \mathrm{mg} \cdot \mathrm{dl}^{-1}$ appear to be deleterious, ${ }^{40}$ particularly in areas of potential collateral flow. ${ }^{41}$

Optimal glucose management during candiopulmonary bypass remains contentious, however. A lower positive fluid balance with no difference in gross neurological outcome was demonstrated in patients in whom a dextrose infusion was utilized during CPB..$^{42}$ Others have been unable to demonstrate any relationship between blood glucose concentrations and postoperative neuropsychological outcome..$^{43}$ A large body of literature in both patients and animal models indicates there is a direct correlation between hyperglycaemia and worsened neurological outcome, however. ${ }^{38}$ In an authoritative editorial, conservative glucose management with employment of intravenous solutions that do not contain glucose was recently recommended. ${ }^{38}$

\section{Pharmacological cerebroprotectants}

In the context of $\mathrm{CPB}$, potentially cerebroprotective agents could function to induce metabolic suppression to increase tolerance for ischaemia, prevent neuronal depolarization by stabilizing cell membranes, scavenge calcium ions or other neurotoxic mediators, or effect a primary decrease in CBF to decrease embolic delivery to the brain. In two clinical trials, metabolic suppression with thiopentone has produced variable results. One study using unfiltered arterial lines and bubble oxygenators during what was essentially normothermic CPB for valvular heart surgery, was able to show a reduction in persisting neurological deficits in the thiopentone-treated group. ${ }^{44} \mathrm{~A}$ more recent study in patients undergoing $\mathrm{CAB}$ surgery with hypothermic CPB was unable to show any benefit associated with thiopentone infusion and was associated with higher requirements for inotropic therapy and longer duration of postoperative ventilation. ${ }^{45}$ As has been elucidated in an editorial overview, it is likely that primary metabolic suppression will not produce major benefit since such cerebral protection has only been demonstrated in models of incomplete focal ischaemia in which the ischaemic insult was sustained for considerably less than ten minutes. ${ }^{46}$ A preliminary report, demonstrating some efficacy of nimodipine in improving cognitive function after CPB in contrast to an untreated control group, suggests that biochemical effects, particularly those associated with inhibition of transmembrane calcium flux and suppression of excitatory amino acids, may be efficacious. ${ }^{47}$

Free radical scavengers, including allopurinol and methylprednisolone, have not consistently demonstrated benefit in experimental ischaemic brain injury. A new series of 21-aminosteroid compounds ("lazaroids", e.g., tirilazad) that do not produce hyperglycemia have demonstrated considerably improved outcome in several exper- 
imental paradigms involving ischaemic neuronal injury. During cerebral ischaemia, FFA production is decreased by administration of calcium antagonists and 21aminosteroids, potent inhibitors of lipid peroxidation and highly effective free radical scavengers. Tirilazad has been shown to produce a reduction in neurological deficits in an animal model after multiple cerebral embolism..$^{48}$ and is currently undergoing clinical trials. Influx of $\mathrm{Ca}^{++}$can be minimized by calcium antagonists. Massive calcium influx is likely the final mediator of ischaemic neuronal injury. Calcium-channel antagonists (nicardipine, nimodipine) have demonstrated efficacy in clinical trials decreasing vasopasms after subarachnoid haemorrhage. Nimodipine has been shown to decrease the incidence of cognitive dysfunction after CPB. ${ }^{47}$ Because of the recognition of excitotoxicity as central to ischaemic neuronal injury, EAA receptor antagonists are being actively investigated. While clinical studies are not currently available, NMDA receptor antagonist MK-801 (dizocilpine) has shown promise experimentally, in studies where two hour DHCA was employed in dogs. ${ }^{49}$ Dizocilpine treatment resulted in better neurological recovery and less neuronal injury, with preservation of post-synaptic NMDA receptors, in comparison to untreated animals. Ketamine is a clinical anaesthetic that is also a noncompetitive NMDA antagonist, and may have cerebroprotective properties. Administration of AMPA receptor antagonists (e.g., CNQX) has also resulted in decreased ischaemic injury, experimentally. In the context of clinical management of patients at risk for cerebral ischaemia, it now seems likely that soon it will no longer be a case of whether cerebroprotective agents will be administered, but rather which agents and at what juncture. The future awaits.

\section{References}

1 Padayachee TS, Parsons S, Theobold $R$, et al. The detection of microemboli in the middle cerebral artery during cardiopulmonary bypass: a transcranial Doppler ultrasound investigation using membrane and bubble oxygenators. Ann Thorac Surg 1987; 44: 298-302.

2 Pearson DT, Holden MP, Poslad SJ, et al. A clinical evaluation of the performance characteristics of one membrane and five bubble oxygenators: gas transfer and gaseous microemboli production. Perfusion 1986; 1: 15-26.

3 Padayachee TS, Parsons S, Theobold $R$, et al. The effect of arterial filtration on reduction of gaseous microemboli in the middle cerebral artery during cardiopulmonary bypass. Ann Thorac Surg 1988; 45: 647-9.

4 Pugsley $W$, Klinger L, Paschalis B, et al. Microemboli and cerebral impairment during cardiac surgery. Vasc Surg 1990; 34-43.

5 Stump DA, Rogers AT, Kon ND, Wallenhaupt SL, Ham- mon JW. When emboli occur during coronary artery bypass graft surgery. Anesthesiology 1993; 79: A49.

6 Blauth CI, Smith PL, Arnold JV, et al. Influence of oxygenator type on the prevalence and extent of microembolic retinal ischemia during cardiopulmonary bypass. J Thorac Cardiovasc Surg 1990; 99: 61-9.

7 Moody DM, Bell MA, Challa VR, Johnston WE, Prough $D S$. Brain microemboli during cardiac surgery or aortography. Ann Neurol 1990; 28: 477-86.

8 Shaw PG, Bates D, Cartidge NEF, Heaviside D, Julian $D G$, Shaw $D A$. Early neurological complications of cardiopulmonary bypass surgery. BMJ 1985; 291: 1384-7.

9 Smith PLC, Newman SP, Ell PJ, Harrison MJ, Treasure $T$, Joseph P, Schneidau A. Cerebral consequences of cardiopulmonary bypass. Lancet 1986; i: 823-5.

10 Murkin JM, Martzke JS, Buchan AM, Bentley C, Wong $C J$. A randomized study of the influence of perfusion technique and $\mathrm{pH}$ management strategy in 316 patients undergoing coronary bypass surgery: (Part 2) neurological and cognitive outcomes. J Cardiovasc Tharac Surg 1995 (in press).

11 Shaw PJ, Bates D, Cartlidge NEF, et al. Neurologic and neuropyschological morbidity following major surgery: comparison of coronary artery bypass and peripheral vasılar surgery. Stroke 1987; 18: 700-7.

12 Carella F, Travaini G, Contri P, Guzzetti S, Botta M, Pieri $E$, Mangoni $A$. Cerebral complications of coronary bypass surgery. A prospective study. Acta Neurol Scand 1988; 77: 158-63.

13 Gravlee GP, Hudspeth AS, Toole JF. Bilateral brachial paralysis from watershed infarction after coronary artery bypass. J Thorac Cardiovasc Surg 1984; 88: 742-7.

14 Smith DS, Levy W, Maris M, Chance B. Reperfusion hyperoxia in brain after circulatory arrest in humans. Anesthesiology 1990; 75: 12-9.

15 Murkin JM. Cerebrovascular reactivity after transient circulatory arrest. Stroke 1992; 23: 3; 467.

16 Ljunggren B, Ratcheson RA, Siesjo BK. Cerebral metabolic state following complete compression ischemia. Brain Res 1974; 73: 291-307.

17 Ljunggren $B$, Schutz H, Siesjo BK. Changes in energy state and acid-base parameters of the rat brain during complete compression ischemia. Brain Res 1974; 73: 277-89.

18 Murkin JM, Martzke JS, Yee R, Giles D. The incidence of cognitive dysfunction following induced ventricular fibrillation corelates with reperfusion interval. Anesth Analg 1995; 80: $\mathrm{S} 333$.

19 Adams DC, Heyer EJ, Emerson MD, et al. Implantable cardioverter defibrillator: evaluation of neurologic outcome and change after implantation. Anesthesiology 1993; 79: A214.

20 Greeley WJ, Kern FH, Ungerleider RM, et al. The effect of hypothermic cardiopulmonary bypass and total circula- 
tory arrest on cerebral metabolism in neonates, infants, and children. J Thorac Cardiovasc Surg 1991; 101: 783-94.

21 Newburger JW, Jonas RA, Wernovsky G, et al. A comparison of the perioperative neurologic effects of hypothermic circulatory arrest versus low-flow cardiopulmonary bypass in infant heart surgery. N Engl J Med 1993; 329: 1057-64.

22 Watanabe $T$, Miura $M$, Orita $H$, Kobayasi $M$, Washio $M$. Brain tissue $\mathrm{pH}$, oxygen tension, and carbon dioxide tension in profoundly hypothermic cardiopulmonary bypass. $\mathrm{J}$ Thorac Cardiovasc Surg 1990; 100: 272-80.

23 Jonas $R A$, Bellinger $D C$, Rappaport $L A$, et al. Relation of $\mathrm{pH}$ strategy and developmental outcome after hypothermic circulatory arrest. J Thorac Cardiovasc Surg 1993; 106: 362-8.

24 Bachet J, Guilmet D, Goudot B, et al. Cold cerebroplegia. J Thorac Cardiovasc Surg 1991; 102: 85-94.

25 Rossen $R$, Kabat H, Anderson JP. Acute arrest of cerebral circulation in man. Arch Neurol Psychiat 1943; 50: 510-28.

26 Prior $P F$. EEG monitoring and evoked potentials in brain ischemia. Br J Anaesth 1985; 57: 63-81.

27 Boretsky RH, Levy WJ. Cerebral hypoxia during ventricular dysrhythmias. Soc Cardiovasc Anesth 1990; 12: A47.

28 Hirsch H, Bolle A, Schaudig A, Tonnis $D$. Uber die wiederbelebung des gehirns bei hypothermie. Pflugers Arch ges Physiol 1957; 265: 328-36.

29 Miller JR, Myers RE. Neurological effects of systemic circulatory arrest in the monkey. Neurology 1970; 20: 715-24.

30 Goldberg ND, Passonneau JV, Lowry OH. Effects of changes in brain metabolism on the levels of citric acid cycle intermediates. J Biol Chem 1966; 241: 3997-4003.

31 Kirsch $W M$, Leitner $J W$. Glycolytic metabolites and cofactors in human cerebral cortex and white matter during complete ischemia. Brain Res 1967; 4: 358-68.

32 Lowry OH, Passonneau JV. The relationship between substrates and enzymes of glycolysis in brain. $\mathrm{J}$ Biol Chem 1964; 239: 31-42.

33 Winn $H R$, Rubio $R$, Berne RM. Brain adenosine production in the rat during 60 seconds of ischemia. Circ Res 1979; 45: 486-92.

34 Rothman SM. Excitotoxins: possible mechanisms of action. Ann NY Acad Sci 1992; 648: 132-9.

35 Minamisawa $H$, Nordstrom $C-H$, Smith $M-L$, Siesjo $B K$. The influence of mild body and brain hypothermia on ischemic brain damage. J Cereb Blood Flow Metab 1990; 10: 365-74.

36 Busto $R$, Dietrich WD, Globus $M Y$-T, Valdes I, Scheinberg $P$, Ginsberg $M D$. Small differences in intraischemic brain temperature critically determine the extent of ischemic neuronal injury. J Cereb Blood Flow Metab 1987; 7: 729-38.

37 Chopp M, Welch KMA, CD Tidwell, Knight R, Halpern
$J A$. Effect of mild hyperthermia on recovery of metabolic function after global cerebral ischemia in cats. Stroke 1988; 19: 1521-5.

38 Lanier $W$. Glucose management during cardiopulmonary bypass: cardiovascular and neurologic implications (Editorial). Anesth Analg 1991; 72: 423-7.

39 Rechncrona S, Kagstrom E. Tissue lactic acidosis and ischemic brain damage. Am J Emerg Med 1983; 2 : 169-72.

40 Berger $L$, Hakim AM. The association of hyperglycemia with cerebral edema in stroke. Stroke 1986; 17: 865-71.

41 Prado $R$, Ginsberg MD, Dietrich WD, Watson BD, Busto $R$. Hyperglycemia increases infarct size in collaterally perfused but not end-arterial vascular territories. J Cereb Blood Blow Metab 1988; 8: 186-92.

42 Metz S, Keats AS. Benefits of a glucose-containing priming solution for candiopulmonary bypass. Anesth Analg 1991; 72: 428-34.

43 Frasco P, Croughwell N, Blumenthal J, et al. Association between blood glucose levels during cardiopulmonary bypass and neuropsychiatric outcome. Anesthesiology 1991; 75: A55.

44 Nussmeier NA, Arlund C, Slogoff S. Neuropsychiatric complications after cardiopulmonary bypass: cerebral protection by a babiturate. Anesthesiology 1986; 64: 165-70.

45 Zaiden JR, Klochany A, Martin WM, Zeigler JS, Harless $D M$, Andrews $R B$. Effect of thiopental on neurologic outcome following coronary artery bypass grafting. Anesthesiology 1991; 74: 406-11.

46 Todd MM, Warner DS. Cerebral metabolic depression and brain protection during ischemia. Anesthesiology 1992; 76: 161-4.

47 Forsman M, Tubylewicz OB, Semb G, Steen PA. Effects of nimodipine on cerebral blood flow and neuropsychological outcome after cardiac surgery. Br J Anaesth 1990; 65: 514-20.

48 Clark WM, Hotan T, Lauten JD, Coull BM. Therapeutic efficacy of tirilazad in experimental multiple cerebral emboli: a randomized, controlled trial. Crit Care Med 1994; 22: 1161-6.

49 Redmond JM, Gillinov AM, Zehr KJ, et al. Glutamate excitotoxicity: a mechanism of neurologic injury associated with hypothermic circulatory arrest. J Thorac Cardiovasc Surg 1994; 107: 776-87. 


\title{
La neuroprotection, l'anesthésie et le cerveau
}

\author{
John Murkin MD FRCPC
}

En clinique, l'anesthésiste doit faire face à l'ischémie cérébrale focale et globale au cours de situations variées provenant en particulier de la chirurgie cardiaque et de l'arrêt circulatoire. Nous ferons la revue de mécanismes lésionnels de l'embolisation cérébrale et de lischémie globale, et nous discuterons du rôle de l'excitotoxicité et des interventions pharmacologiques potentielles.

\section{Ischémie focale}

Des preuves directes et indirectes nous démontrent que l'ischémie focale survient pendant la circulation extracorporelle (CEC) à la suite de microembolies gazeuses ou matérielles. Le risque d'embolies est influencé par plusieurs facteurs dont la technique de CEC, par ex., l'incorporation de filtres sur les canalisations artérielles, le type d'oxygénateur utilisé (à membrane vs à bulles). ${ }^{1-4}$ De plus, des études au Döppler transcrânien (DTC) ont décelé des embolies survenant aussi bien au moment de la canulation et du clampage de l'aorte que pendant une CEC stable. ${ }^{5}$ L'imagerie rétinienne a montré des anomalies perfusionnelles caractéristiques de l'embolisation qui sont atténuées lorsqu'un oxygénateur à membrane est utilisé. ${ }^{6}$ Des études histologiques réalisées à la fois chez l'animal et l'humain sous CEC mais aussi chez des patients soumis uniquement à une aortographie proximale, ont montré des lésions microvasculaires cérébrales compatibles avec les embolies cérébrales. ${ }^{7}$

Indépendamment des microembolies, l'athérosclérose étendue de l'aorte représente un risque vraisemblable et autonome de dommages neurologiques et d'accidents cérébrovasculaires. Ceci résulte à la fois de la rupture et de la fragmentation provoquées par les manipulations instrumentales de l'aorte aussi bien que par le cisaillement de la plaque athéromateuse consécutif aux altérations hydrodynamiques provoquées par la perfusion à travers la canule aortique. Le risque de dysfonctionnement neurologique associé à la chirurgie sous CEC est en général inférieur à $2 \% .^{8,9} \mathrm{Il}$ existe par contre une incidence élevée de dysfonctionnement neuropsychologique postopératoire subtil qui se situe entre $48 \%$ et $79 \%$ des patients soumis à une chirurgie de revascularisation coronaire. ${ }^{8,10-12}$ L'étiologie et l'importance de ce dysfonctionnement cognitif sont mal connus, mais semblent refléter l'ischémie cérébrale causée par des épisodes d'hypoperfusion ${ }^{13}$ et/ ou de microembolies gazeuses et solides survenues pendant la CEC. ${ }^{7,8}$ De plus, ce dysfonctionnement cognitif est aussi, en partie, attribuable au stress non spécifique de la chirurgie majeure indépendant de la CEC.

\section{Lischémie globale}

En clinique, les épisodes d'ischémies globales contrôlées sont propres aux interventions pour implantation de cardioconvertisseurs-défibrillateurs (ICD) et à celles qui se réalisent sous arrêt cardiaque en hypothermie profonde (ACHP), comme, par ex., la reconstruction de l'arche aortique et la réparation de lésions cardiaques congénitales. Comme les ICD nécessitent de nombreux épisodes d'arrêts cardiaques, ces interventions, particulièrement lorsqu'elles s'ajoutent à une maladie cérébrovasculaire à son début ou établie (on l'estime présente chez plus de $60 \%$ des patients qui souffrent de maladie cardiaque athérosclérotique) provoquent de nombreux épisodes d'ischémie cérébrale globale. Bien que les épisodes de tachycardie ventriculaire ou de fibrillation soient limités à 60 secondes ou moins, ils sont suffisants pour faire perdre conscience, arrêter le débit sanguin cérébral et perturber temporairement l'activité métabolique cérébrale.

Dans une des rares études cliniques de la physiologie cérébrale réalisée chez des patients soumis à l'ICD, ${ }^{14}$ une réaction hyperoxique de reperfusion a été constatée après des épisodes d'arrêts circulatoires de plus de 37 secondes. L'importance de la réaction de reperfusion cérébrale correspond approximativement à la durée de l'arrêt circulatoire. La réponse de reperfusion hyperoxique constitue vraisemblablement une vasodilatation transitoire cérébrale post-ischémique qu'on peut observer avec le DTC pendant les interventions pour ICD. ${ }^{\text {is }}$ Ceci prouve la nécessité d'une reperfusion cérébrale dont la durée n'est pas bien quantifiée. De rares études ont examiné, une heure ou plus après de brefs épisodes d'ischémie cérébrale globale, la vitesse de récupération de la fonction métabolique cérébrale; nous ne possédons malheureusement pas d'études portant sur la vitesse de récupération du métabolisme cérébral réalisées en deçà de quelques minutes d'un événement ischémique de courte durée. Dans les études déjà mentionnées, on note qu'après 60 secondes d'ischémie suivies par $90 \mathrm{~min}$ de reperfusion, la phosphocréatinine $(\mathrm{PCr})$ et les niveaux d'adénosine triphos- 
phate (ATP) demeurent encore sous les valeurs de contrôle bien que le lactate, la charge d'énergie d'adenylate et le rapport lactate/pyruvate soient revenus aux valeurs de contrôle. ${ }^{16,17}$ Les signes de dysfonctionnement cognitifs postopératoires observés chez les patients qui ont subi une ICD sont variables, ${ }^{18}$ mais récemment on a rapporté que l'intervalle de reperfusion entre les périodes successives d'ischémie induites par la FV était critique, le dysfonctionnement neuropsychologique n'etant observé qu'après des intervalles de reperfusion de trois minutes ou moins, mais pas après ceux qui dépassaient quatre min. ${ }^{19} \mathrm{Ceci}$ montre que la pratique courante qui varie d'un centre à l'autre et d'un intervenant à un autre devrait favoriser un intervalle de reperfusion de cinq minutes au moins pour obtenir une récupération cérébrale valable entre l'induction d'épisodes arythmiques successifs.

\section{L'arrêt circulatoire en hypothermie profonde}

L'hypothermie constitue l'élément principal de la protection cérébrale pendant l'ACHP. Pour une fourchette de valeurs situées entre $37^{\circ}$ et $17^{\circ} \mathrm{C}$ (moyenne $20^{\circ} \mathrm{C}$ ), le coefficient de température (Q10) du cerveau est en moyenne de $3,65,{ }^{20}$ ce qui signifie que la tolérance à lisschémie est considérablement augmentée. Diminuer le réchauffement du cerveau est essentiel; les sources de chaleurs externes, par ex., par les scialytiques, par la température ambiante de la pièce, devraient être atténuées. Des expériences ont montré que l'application de sacs de glace sur la tête diminuait le réchauffement du cerveau et augmentait la tolérance à l'ischémie. Parce que l'autorégulation cérébrale favorise le shunt préférentiel du sang vers le cerveau, même les bas débits de perfusion (par exemple, $10-25 \mathrm{ml} \cdot \mathrm{kg}^{-1} \cdot \mathrm{min}^{-1}$ ), pendant l'hypothermie profonde, améliorent la tolérance ischémique cérébrale comparativement à l'arrêt circulatoire total. Une étude récente prospective et randomisée a rapporté une incidence moins élevée de crises convulsives postopératoires chez les enfants soumis à une chirurgie cardiaque sous CEC à bas débit $\left(0,7 \mathrm{~L} \cdot \mathrm{m}^{2} \cdot \mathrm{min}^{-1}\right)$ en comparaison avec l'ACHP. Des études expérimentales pendant l'ACHP ont montré que le refroidissement du cerveau était plus homogène avec le pH-stat alors que l'alpha-stat était associé à une acidose intracellulaire moindre qu'avec le $\mathrm{pH}$-stat pendant le réchauffement. ${ }^{22}$ Cependant, au cours d'une étude rétrospective portant sur linfluence de la gestion du $\mathrm{pH}$ sur le développement ultérieur après l'ACHP, on a conclu que l'alpha-stat procurait une protection cérébrale moins efficace. ${ }^{23}$

Pour les interventions sur l'arche aortique au cours desquelles le débit artériel est limité, une perfusion cérébrale sélective par canulation brachiocéphalique ou carotidienne a été utilisée avec succès. ${ }^{24}$ On manifeste présentement plus d'intérêt pour la perfusion cérébrale rétrograde réalisée par une canule SVC, bien que les études cliniques de résultats ne soient pas disponibles. Il semble que, indépendamment de la composition du substrat des solutions cérébroplégiques, le lavage des métabolites toxiques et la prévention du réchauffement précoce du cerveau sont des facteurs d'une importance capitale pour la protection cérébrale pendant l'ACHP.

\section{Altérations fonctionnelles et biochimiques pendant lischémie}

Le ralentissement des ondes de l'EEG avec augmentation des épisode de basses fréquences (bande delta) révèle l'ischémie cérébrale. ${ }^{25}$ Pendant l'anesthésie, l'intervalle compris entre début de l'arrêt circulatoire et l'apparition de l'ischémie sur l'EEG est de 20 secondes. ${ }^{26,27} \mathrm{Chez}$ l'animal, après l'arrêt circulatoire, l'EEG disparaît en 15 à 25 secondes, le réflexe cornéen en 10 à 90 secondes et la respiration spontanée en 30 à 120 secondes. ${ }^{28}$ Des études d'ischémies globales totales réalisées avec des garrots cervicaux chez des sujets normaux et schizophrènes ont montré une perte de conscience en six à sept secondes avec un ralentissement concomitant de l'EEG suivi par l'isoélectricité après 20 à 40 secondes. ${ }^{25}$ Des crises convulsives toniques et des périodes de confusion transitoires suivent les épisodes ischémiques maintenus pendant au moins 100 secondes. ${ }^{25}$ Chez le singe, lischémie globale cérébrale d'une durée de trois minutes ou plus provoque des déficits neurologiques fonctionnels à récupération lente ou définitifs. ${ }^{29}$ Les réserves cérébrales en oxygène sont épuisées après quelques secondes disschémie. Des changements biochimiques, dont une réduction de $50 \%$ de l'ATP et une diminution de $85 \%$ de la PCr surviennent après 30 secondes d'ischémie globale chez la souris; ${ }^{30}$ des changements semblables sont observés dans le cortex cérébral humain. ${ }^{31}$ A la $60^{\mathrm{e}}$ seconde qui suit la décapitation, le cerveau de la souris subit les effets métaboliques suivants: la $\mathrm{PCr}$, le glucose et les réserves de glycogène chutent à moins de $10 \%$, l'ATP est à moins de $25 \%$ du contrôle et le lactate a bondi à $75 \%$ de sa valeur maximale. ${ }^{32}$ Chez le rat, une période de 60 secondes d'ischémie provoque une augmentation de $250 \%$ de l'adénosine et du lactate et des diminutions tangibles de la $\mathrm{PCr}$ sont décelées après les cinq premières secondes d'schémie. ${ }^{33}$ On peut même constater que de brefs périodes dischémie cérébrale peuvent induire des changements fonctionnels et métaboliques profonds chez des animaux et chez l'humain.

La production d'acide gras libre (AGL) à partir des phospholipides de la membrane constitue une des altérations les plus précoces de la membrane cellulaire pendant lischémie. Avec l'ischémie, la déplétion d'ATP produit une perte du gradient ionique provoquant une dépola- 
risation de la membrane cellulaire et l'influx de lion calcium $\left(\mathrm{Ca}^{++}\right)$à travers les canaux sensibles au voltage. L'accumulation intra-cellulaire de l'excès de $\mathrm{Ca}^{++}$conduit à la mort neurale par augmentation du catabolisme des protéines et des lipides. $\mathrm{Le} \mathrm{Ca}^{++}$intra-cellulaire active les phospholipases $\mathrm{C}$ et $\mathrm{A} 2$ dépendantes du calcium, et transforme les phospholipides de la membrane en AGL qui sont en eux-mêmes neurotoxiques. Les AGL sont des puissants découpleurs de la phosphorilation oxydative et peuvent subir une oxydation subséquente à partir de l'acide arachidonique avec la formation de radicaux libres comme résultat. Avec la reperfusion, les voies de la cyclooxygénase mitochrondrique et de la lipooxygénase, en association avec l'oxydation des AGL, sont principalement responsables de l'augmentation de radicaux libres (par ex., l'anion superoxyde) qui provoque la destruction cellulaire oxydative.

\section{Excitotoxicité}

L'excitotoxicité induite par neurotransmetteurs peut constituer la voie finale commune de la production de la lésion ischémique cérébrale. ${ }^{34}$ Le glutamate et l'aspartate sont des aminoacides neurotransmetteurs excitateurs (AAE) avec trois sous-types distincts de récepteurs postsynaptiques, le N-méthyl-D-aspartate (NMDA), le kainate (KA) et le quisqualate/alpha-méthyl propionic acid (AMPA), responsables de la médiation du calcium et du transfert du sodium et du potassium. L'ischémie produit une libération présynaptique massive d'AAE, diminue la recapture et active ainsi les récepteurs postsynaptiques du NMDA et de l'AMPA, produisant la sortie massive de $\mathrm{K}^{+}$et l'influx de $\mathrm{Na}^{+}$et de $\mathrm{Ca}^{++}$suivis de l'osmolyse et de la lésion. Les AAE sont aussi responsables de la formation de radicaux libres.

L'hypothermie légère $\left(<35^{\circ} \mathrm{C}\right)$ inhibe considérablement lischémie induite par la libération d'AAE. Chez l'animal, la tolérance à l'ischémie cérébrale se prolonge de façon disproportionnée pendant l'hypothermie légère à $34^{\circ} \mathrm{C} .{ }^{35}$ Chez le rat soumis à une occlusion des quatre vaisseaux cérébraux, malgré une déplétion grave de l'énergie métabolique cérébrale pendant l'ischémie à toutes les températures, les augmentations de la température intracérébrale par plateaux accentuent fortement les changements histopathologiques après une survie de trois jours, de telle sorte qu'on ne trouve pas de neurones ischémiques dans la zone centrale du corps strié chez aucun des rats maintenus à $34^{\circ} \mathrm{C}$, alors qu'on en trouve chez tous les rats dont la température était maintenue à $36^{\circ} \mathrm{C} .{ }^{36}$ Contrairement à l'effet salutaire de l'hypothermie légère, la normothermie et l'hyperthermie à $40,6^{\circ} \mathrm{C}$ diminuent fortement la tolérance à l'ischémie et préviennent la récupération métabolique après une ischémie transitoire cérébrale globale. ${ }^{36,37}$ De l'hyperthermie non détectée ac- compagne souvent la CEC hypothermique. En pratique on peut l'observer pendant la phase de réchauffement lorsque la température nasopharyngée dépasse $38^{\circ} \mathrm{C}$ et peut même atteindre $39^{\circ} \mathrm{C}$, conformément à la température du sang artériel pendant le réchauffement et à la vitesse à laquelle le réchauffement a lieu.

\section{Acidose glucose/lactate}

Le glucose constitue essentiellement le seul substrat de la production d'énergie du cerveau; le glucose est métabolisé pour produire 36 à 38 moles d'ATP par mole de glucose. L'oxygène est essentiel à la phosphorylation oxydative et en présence d'ischémie, le métabolisme anaérobique du glucose ne libère que deux moles d'ATP et produit du lactate avec accumulation de lion hydrogène $\left(\mathrm{H}^{+}\right)$. La glycolyse anaérobique est la principale cause d'acidose pendant l'ischémie et la gravité de l'acidose lactique est directement proportionnelle aux concentrations pré-ischémiques de glucose. ${ }^{38} \mathrm{Ceci}$ reflète la conversion du glucose en lactate, avec comme résultat une diminution du $\mathrm{pH}$ intracellulaire et du métabolisme cellulaire principalement causée par l'inhibition de la fonction mitochondrique pendant l'ischémie et la reperfusion. Pendant l'ischémie partielle, le " goutte à goutte " de glucose au cerveau aboutit au métabolisme lactique et à l'aggravation de l'acidose. ${ }^{39}$ Des études cliniques ont montré que des valeurs de glycémie plus élevées que $150 \mathrm{mg} \cdot \mathrm{dl}^{-1}$ semblaient nuisibles ${ }^{40}$ particulièrement dans les régions de débit collatéral potentiel. ${ }^{41}$

La gestion optimale du glucose pendant la CEC demeure controversée. On a trouvé une balance liquidienne positive plus basse sans modification de l'etat neurologique chez les patients qui avaient reçu une perfusion de dextrose pendant la CEC. ${ }^{42}$ D'autres n'ont pas réussi à montrer de relation entre les concentrations du glucose sanguin et le devenir neuropsychologique postopératoire. ${ }^{43}$ Plusieurs articles concernant patients et animaux indiquent cependant qu'il existe une corrélation directe entre l'hyperglycémie et l'aggravation du devenir neurologique. ${ }^{38}$ Un éditorial récent qui fait autorité recommande la gestion conservatrice de la glycémie par l'utilisation de solutions intraveineuses qui ne contiennent pas de glucose. ${ }^{38}$

\section{Protection cérébrale pharmacologique}

Dans le contexte de la CEC, les agents protecteurs du cerveau pourraient induire la suppression métabolique pour augmenter la tolérance à l'ischémie, prévenir la dépolarisation des neurones en stabilisant les membranes cellulaires, récupérer les ions calciques et autres médiateurs neurotoxiques, ou diminuer d'abord le débit sanguin cérébral pour réduire le transport d'embolies au cerveau. Au cours de deux essais cliniques, la suppression méta- 
bolique par le thiopental a produit des résultats variables. Une étude qui utilisait des lignes artérielles non filtrées et des oxygénateurs à bulles, pendant une CEC essentiellement normothermique pour la chirurgie cardiaque valvulaire, a pu montrer une réduction des déficits neurologiques persistants dans le groupe traité au thiopental. ${ }^{44}$ Une étude récente chez les malades soumis à une chirurgie de revascularisation coronaire sous CEC hypothermique n'a pas été capable de démontrer les bénéfices de la perfusion de thiopental, et était associée à une augmentation des besoins inotropiques et de la durée de la ventilation postopératoire. ${ }^{45}$ Comme l'énonçait un éditorial, il est vraisemblable que la suppression métabolique primaire ne produise pas de bénéfices majeurs étant donné que cette protection cérébrale n’a été démontrée que sur des modèles d'ischémie focale incomplète où le traumatisme ischémique n'a été soutenu que pendant dix minutes et moins. ${ }^{46}$ Un rapport préliminaire qui montre que la nimodipine peut améliorer la fonction cognitive après $\mathrm{CEC}$, comparativement à un groupe non traité, suggère que ses effets biochimiques pourraient être efficaces, particulièrement ceux qui sont associés à l'inhibition du flux calcique transmembranaire et à la suppression des acides aminés neuroexcitateurs. ${ }^{47}$

Les épurateurs de radicaux libres comme l'allopurinol et la méthylprednisolone n'ont pas, de façon constante, présenté de bénéfices au regard de la lésion ischémique cérébrale expérimentale. Une nouvelle série de composés 21-aminostéroïdes (les « lazaroïdes ", par ex., le tirilazad) qui ne provoquent pas d'hyperglycémie ont montré sur plusieurs modèles expérimentaux qu'ils pouvaient améliorer le devenir après une lésion neuronale ischémique. Pendant l'ischémie cérébrale, la production d'AGL est diminuée par l'administration des inhibiteurs calciques et des 21-aminostéroïdes qui sont de puissants inhibiteurs de la peroxydation lipidique et des épurateurs efficaces de radicaux libres. Le tirilazad a fait la preuve quil produisait une réduction des déficits neurologiques sur un modèle animal après des embolies cérébrales multiples ${ }^{48}$ et est présentement soumis à des essais cliniques. L'influx de $\mathrm{Ca}^{++}$peut être minimisé par les inhibiteurs calciques. L'influx massif du calcium est vraisemblablement le médiateur décisif de la lésion ischémique neuronale. Les inhibiteurs calciques (nicardipine, nimodipine) ont fait la preuve de leur efficacité au cours d'essais cliniques en diminuant le vasospasme après l'hémorragie sousarachnoïdienne. La nimodipine a montré qu'elle diminuait l'incidence du dysfonctionnement cognitif après la CEC. ${ }^{47}$ Maintenant que l'excitotoxicité est reconnue comme le coeur de la lésion neuronale ischémique, l'attention se porte sur les antagonistes des récepteurs des AAE. Bien que des études cliniques ne soient pas disponibles actuellement, l'antagoniste du récepteur du
NMDA, le MK-801 (dicozilpine) semble prometteur en laboratoire, dans des études où l'ACHP a été réalisée sur des chiens pendant deux heures. ${ }^{49}$ Le traitement à la dicozilpine a permis une meilleure récupération neurologique et moins de lésions neuronales, avec préservation des récepteurs postsynaptiques du NMDA comparativement aux animaux non traités. La kétamine est une anesthésique antagoniste non compétitif du NMDA et pourrait avoir des propriétés protectrices cérébrales. L'administration des antagonistes de l'AMPA (par ex., le $(N Q X)$ atténue aussi la lésion cérébrale ischémique en laboratoire. Dans le contexte de la gestion des patients à risque d'ischémie cérébrale, il semble vraisemblable que bientôt nous cesserons de nous demander si des agents neuroprotecteurs devraient être administrés mais bien lesquels et dans quelles situations. L'avenir nous le dira.

\section{Références}

(Voir page R112) 